\title{
Evidence of STLV 2 and STLV 3 infections in wild living bonobos (P. paniscus) from the Democratic Republic of Congo
}

\author{
Steve Ahuka-Mundeke ${ }^{1,2^{*}}$, Florian Liegeois ${ }^{1}$, Octavie Lunguya ${ }^{2}$, Valentin Mbenzo ${ }^{3}$, Menard Mbende ${ }^{3}$, \\ Bila-Isia Inogwabini ${ }^{3}$, Ahidjo Ayouba', Jean-Jacques Muyembe ${ }^{2}$, Eric Delaporte ${ }^{1}$, Martine Peeters ${ }^{1 *}$ \\ From 15th International Conference on Human Retroviruses: HTLV and Related Viruses \\ Leuven and Gembloux, Belgium. 5-8 June 2011
}

\section{Background}

Among the four types of HTLV (1,to 4), only three have their simian counterparts (STLV-1, 2 and 3). STLV-1 and 3 have been found in a large number of captive and wild-living monkeys and great apes from Africa and Asia. STLV-2 was reported only in a limited number of captive bonobos (P. paniscus) from Democratic Republic of Congo (DRC), but so far never documented in wildliving populations.

\section{Material and methods}

Between March and July 2010, fecal samples from wildliving bonobos were collected at Malebo forest in the Bandundu province, western DRC. We confirmed the species by mitochondrial (mt) DNA analyses and we screened all samples for STLV infection using a generic PCR allowing amplification of partial fragment in tax (220bp) as well as targeting different fragments in the LTR.

\section{Results}

We collected a total of 268 bonobos fecal samples. Overall, $3(1.1 \%)$ samples amplified the tax fragment. Among these, one (Pp5538) was identified as STLV-2 and two (Pp5489 and Pp5560) as STLV-3 by phylogenetic analysis. Additional analysis on the LTR fragment showed that the new STLV-2 from Pp5538 clustered with STLV-2 strains previously described in captive bonobos. All PCR attempts to amplify the LTR fragment of Pp5489 and 5560 samples were unsuccessfull.

\footnotetext{
* Correspondence: martine.peeters@ird.fr

'UMI 233, Institut de Recherche pour le Developpement (IRD) and University of Montpellier 1, Montpellier, France

Full list of author information is available at the end of the article
}

\section{Conclusion}

Our study shows that faecal samples can be used to screen for STLV infection in endangered apes, although most likely with lower sensitivities. We confirmed STLV-2 infection in wild-living bonobos and showed that bonobos are also infected with STLV-3.

\section{Author details}

'UMI 233, Institut de Recherche pour le Developpement (IRD) and University of Montpellier 1, Montpellier, France. ${ }^{2}$ National Institute of Biomedical Research , Kinshasa, Democratic Republic of Congo. ${ }^{3}$ Lac Tumba Project, WWF, Kinshasa,Democratic Republic of Congo.

Published: 6 June 2011

\section{doi:10.1186/1742-4690-8-S1-A93}

Cite this article as: Ahuka-Mundeke et al.: Evidence of STLV 2 and STLV 3 infections in wild living bonobos (P. paniscus) from the Democratic Republic of Congo. Retrovirology 2011 8(Suppl 1):A93.
Submit your next manuscript to BioMed Central and take full advantage of:

- Convenient online submission

- Thorough peer review

- No space constraints or color figure charges

- Immediate publication on acceptance

- Inclusion in PubMed, CAS, Scopus and Google Scholar

- Research which is freely available for redistribution

Submit your manuscript at www.biomedcentral.com/submit
( Biomed Central

\section{Biomed Central}

